\title{
S-40: Acute Phase Protein Increse in High Altitude Mountaineers
}

\author{
Tolga Saka ${ }^{1}$, Mehmet Karakuş ${ }^{2}$ \\ ${ }^{1}$ Spor Hekimliği Anabilimdalı, Bezmialem Vakıf Üniversitesi Tıp Fakültesi, İstanbul, Turkey \\ ${ }^{2}$ Spor Hekimliği Anabilimdalı, Erciyes Üniversitesi Tıp Fakültesi, Kayseri, Turkey
}

\begin{abstract}
"Erciyes Tigers" are an elite group of high altitude climbers. They have been climbing Erciyes

Mountain (3500 m, in Kayseri, Turkey) once a week at least for ten years. When they climb Erciyes in winter, they also take a snow bath. This study investigated the effects of regular high altitude climbing on the metabolic and hematological responses of mountaineers. Venous blood samples were taken to investigate hematological, biochemical parameters and some hormone values from 21 mountaineers and 16 healthy age-matched sedentary volunteers at resting condition. The neutrophil/lymphocyte (N/L) ratio was calculated. The N/L was associated with an increased risk of long-term mortality and it could provide a good measure of exercise stress and subsequent recovery. Most of the hematological and biochemical parameters i.e., erythrocyte, leukocyte, hemoglobin and hematocrit values did not change significantly. The neutrophil to lymphocyte $(N / L)$ ratio was significantly $(p<0.04)$ decreased in the mountaineer compared with the sedentary group. Total protein $(p<0.000)$ and albumin $(0.001)$ were lower, while ferritin $(p<0.04)$, creatine $(p<0.03)$ and creatine phosphokinase levels $(p<0.01)$ were higher in mountaineers. Our results show that regular high altitude climbing increased serum levels of some acute-phase proteins and these increments were not transient.
\end{abstract}

Available at: http://journalofsportsmedicine.org and http://dx.doi.org/10.5152/tjsm.2017.044 